\title{
Effectiveness of group play therapy on depression and loneliness in 7-11 years old children with post-traumatic stress disorder PTSD caused by sexual abuse in Tehran.
}

\begin{abstract}
Background and objective: Recent studies have shown that one of the major effects of child sexual abuse is post-traumatic stress disorder (PTSD). PTSD can be associated with depression and loneliness, which, if untreated, lead to longterm complications. The aim of this research was to study the effectiveness of group play therapy on depression and loneliness in 7-11 years old children with PTSD caused by sexual abuse in Tehran.

Materials and methods: This study was a quasi-experimental with a pre-test, posttest and follow-up design using a control group that was done in 2015. 34 children with PTSD due to sexual abuse were selected through convenience sampling and were randomly assigned to experimental and control groups. The experimental group was treated in 7 sessions with each 1.5 hours by Group play therapy. Loneliness Questionnaire and Children's Depression Inventory were used to collect the data. Data were analyzed by SPSS 20 using analysis of covariance method.

Results: There was significant difference between depression and loneliness in the experimental and control groups $(p=0.000, F=10.646),(p=0.000, F=$ 29.54). By eliminating the effect of pre-test in the follow-up phase, the treatment effect was maintained.

Conclusion: Group play therapy can effectively reduce depression and loneliness in children with PTSD.

Paper Type: Research Article.

Keywords: Group play therapy, Depression, Loneliness, Post-traumatic stress disorder (PTSD), Child sexual abuse, Tehran.

Citation: Amini K, Neshatdoost H.T, Mazaheri M.A., Nadi M.A. Effectiveness of group play therapy on depression and loneliness in 7-11 years old children with post-traumatic stress disorder PTSD caused by sexual abuse in Tehran. Iran J Health Educ Health Promot. Summer 2016;4(2): 130-138.
\end{abstract}

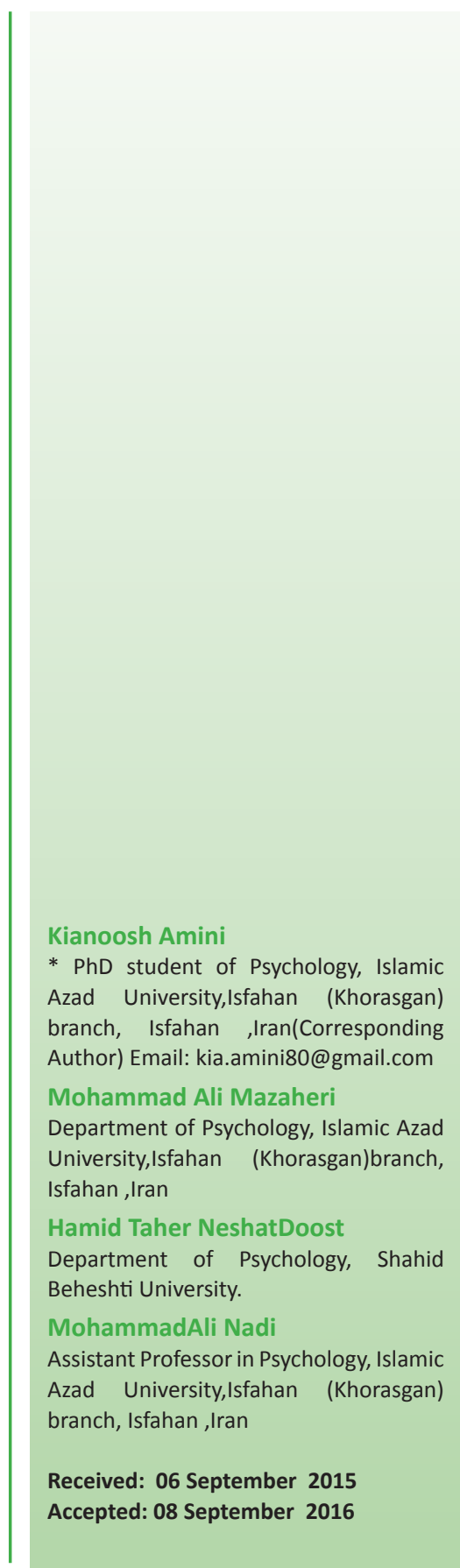




\section{اثربخشى بازىدرمانى كروهى بر ميزان افسردكى و احساس تنهايى كودكان Y- II ساله} داراى اختلال استرس بـس از ضربه ناشى از سوءاستفاده جنسى شهر تهران

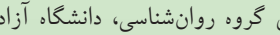
اسلامى واحد اصفهان (خوراسكان)، اصفهان، ايران kia.amini80@gmail.com

$$
\text { (نويسنده مسئول) }
$$

$$
\text { حميد طاهرنشاطدوست }
$$

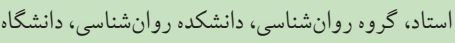
آزاد اسلامى واحد اصفهان (خوراسكان)، اصفهان، ايران دان دانئان

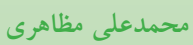
استاد كروه روانشناسي، دانشكده روانشناسى، دانشكاه شهيد بهشتى، تهران، ايران محمد على نادى

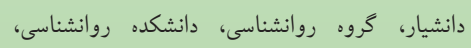

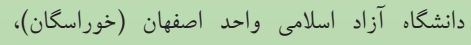

$$
\text { اصفهان، ايران }
$$

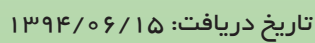

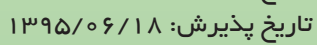

\section{بكيده}

زمينه و هدف : تحقيقات اخير نشان دادهاند كه يكى از عوارض عمده سوءاستفاده جنسى از كود كان اختلال

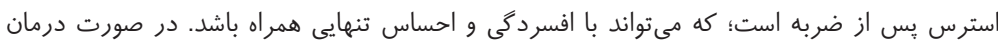

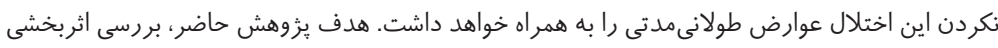

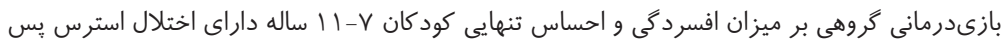

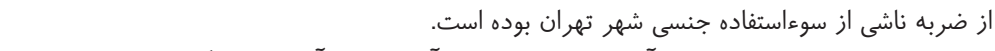

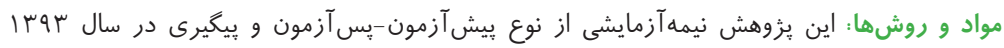

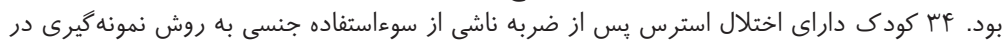

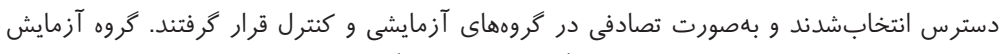

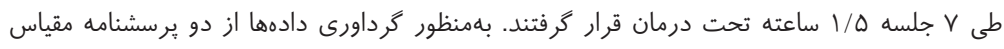

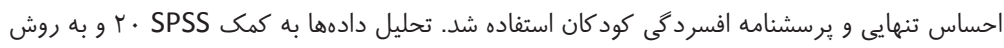

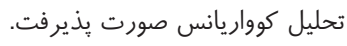

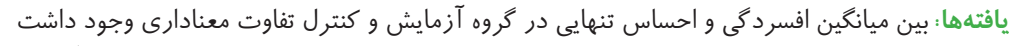

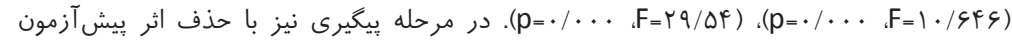

همجنان اثر درمان حفظشده بود.

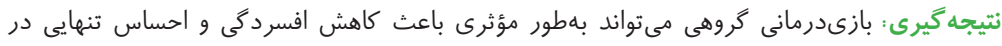

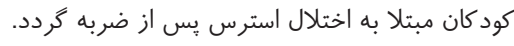

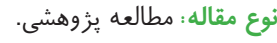

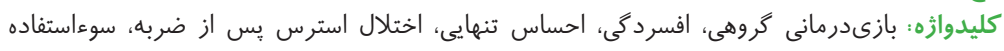

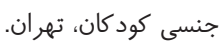

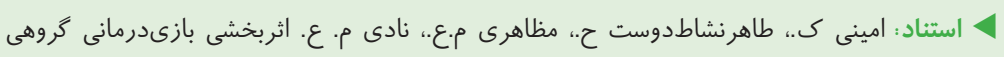

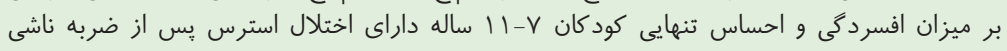

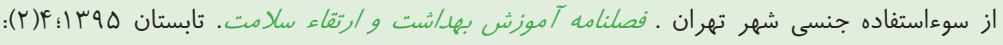


دهند و احساساتشان را بهتر نشان دهند (9). بازىدرمانى شيوهاى

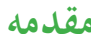
است كه به يارى كودكان بر مشكل مىرود تا هنگامى كه بتوانند مسائل خود را به دست خويش و از طريق بازىهايشان حل كنند.

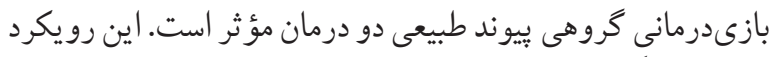
درمانى براى كودكان، يك فرايند روانشناختى و اجتماعى بوده و بستر رشد و ياد گيرى در مورد خودشان و ديخران را فر اهم مى كند.

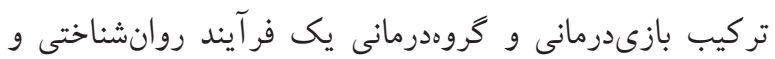

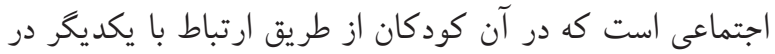

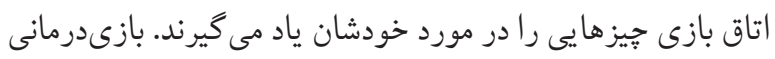

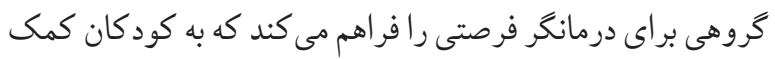

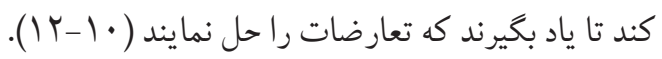

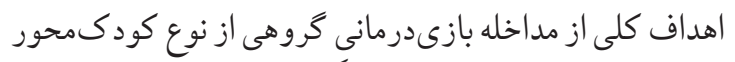
عبارتاند از: كمك به مشار كت ياد گيرى، خود كنترلى، مسئوليت

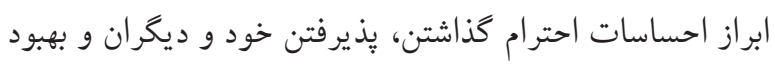

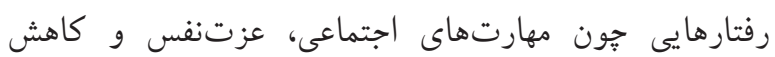

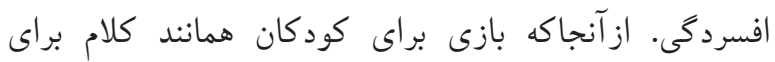
بزرگسالان است و وسيلهاى براى بيان احساسات، برقرارى برى براي

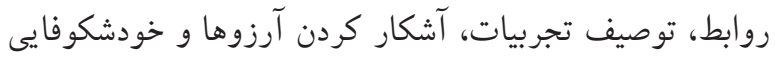

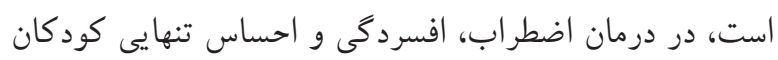

بهعنوان يكى از روشهاى درمانى ترجيح داده مىشود (1 ال). درمان افسردكى و احساس تنهايى كودكان دجار اختلال استرس يس از ضربه ناشى از سوءاستفاده جنسى يكى از از

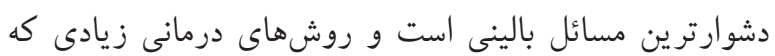
در اين زمينه مؤثر باشند، بهندرت به جشم مىخورد. با بـ توجه

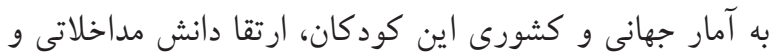

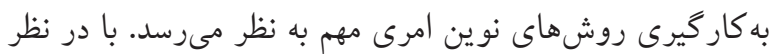

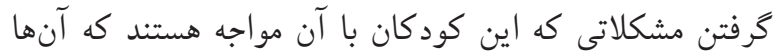

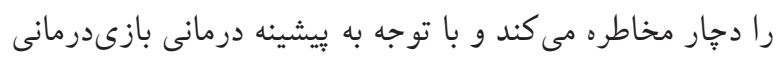

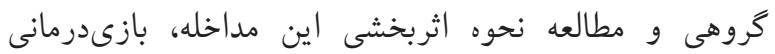
كروهى مى تواند در بهبود افسردگى و احساس تنهايى مؤثر باشد. ازاينرو، هدف كلى اين يُزوهش، مطالعه اثربخشى بازى مرومانى

سوءاستفاده از كودكان يك مشكل جهانى است؛ شيوع آن در كشورهاى درحالتوسعه در مقايسه با كشورهاى توسعهيافته

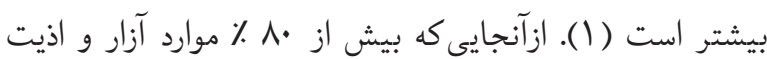
جنسى گزارش نمىشود و حتى سوءرفتارهاى جسمى و عاطفى إنى نيز كمتر نمود بيدا مى كند (Y)، آمار دقيقى از ميزان كود كان

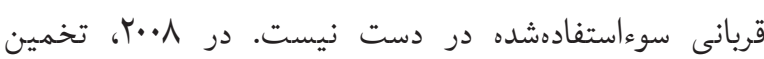

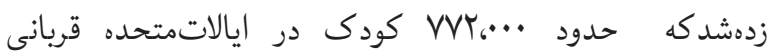

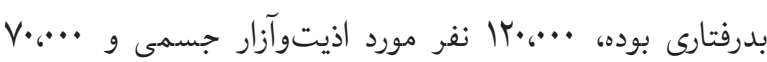

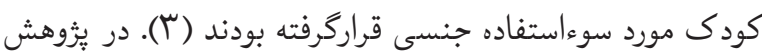
ديخرى بيان كردهاند كه سالانه تقريباً 9 ٪ كود كان از سوءاستفاده بودئ

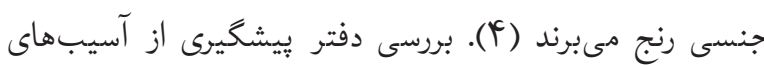

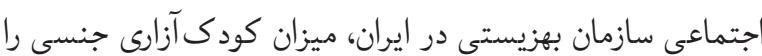

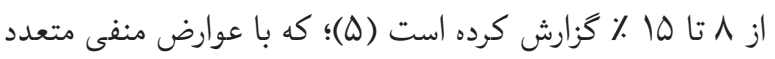

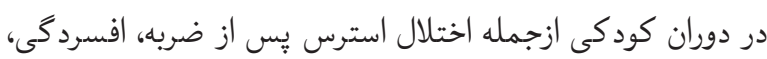

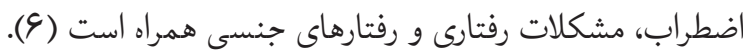

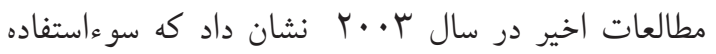
جنسى ممكن است مخرب باشد؛ بهخصوص هنگامى كه در سن

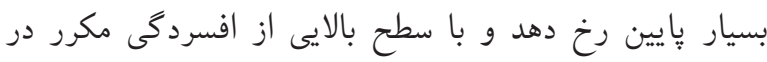

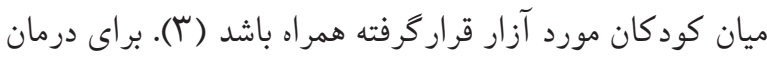
كودكان، مداخلههاى روانشناختى مختلفى وجود دارد؛ ازجمله روشهاى شناختى -رفتارى و بازىدرمانى. بازى افكار درونى

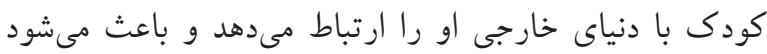

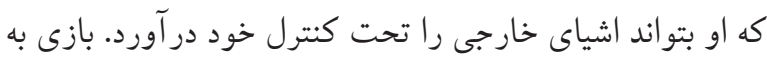

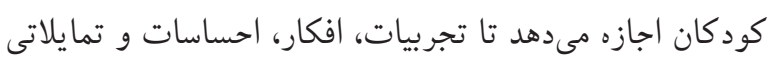

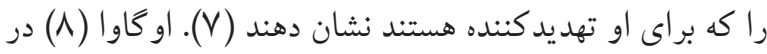

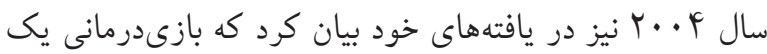

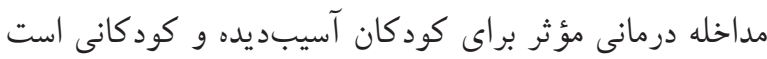

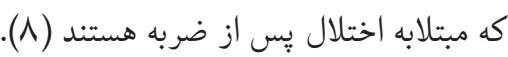
به دليل اينكه كودكان اغلب در بيان شفاهى احساساتشان با بـان مشكل روبرو هستند، از طريق بازى مىتوانند موانع را كاهش 
سه بخش بود: (1) جمعيتشناختى، (Y) مقياس سنجش

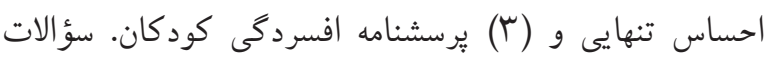

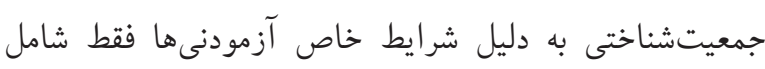
سن و جنس بود. براى سنجش احساس تنهايى از مقياس اشر و ميلر كه براى سنجش احساس تنهايى در اواخر دوران كودكى تردي

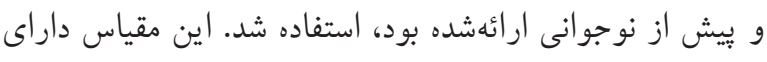

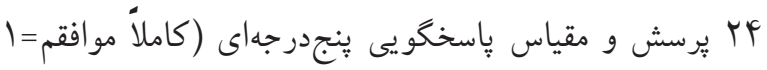

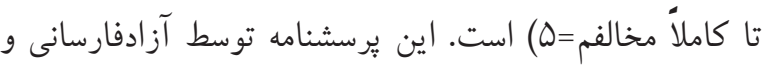

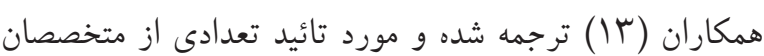
روانشناسى قرار كرفته است. اشر و ميلر در سال 1910 انشان دادند كه احساس تنهايى ميان كودكان طردشده و كودكان ساير

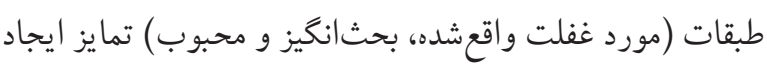

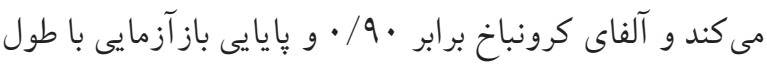

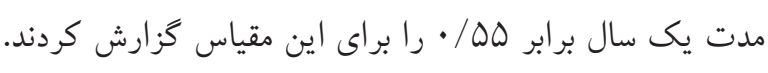

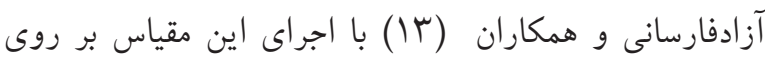

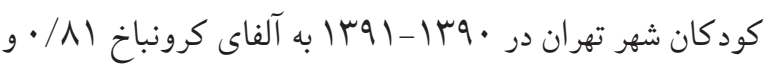

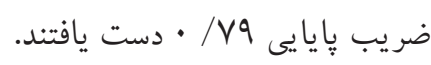
براى ارزيابى شدت افسردىى كود كان از برسشنامه افسردگى إنى

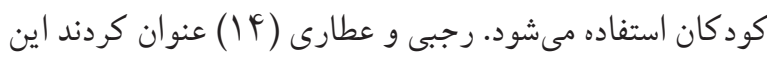

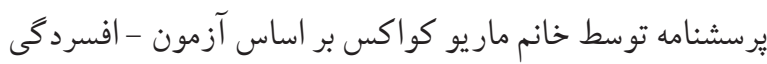

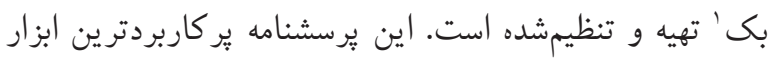

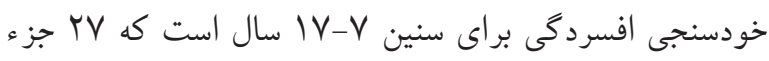

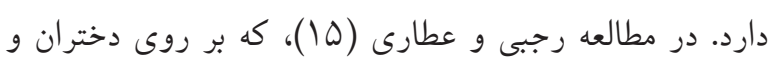

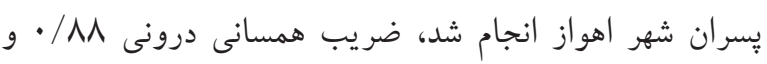

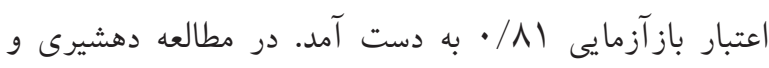

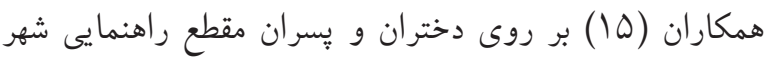

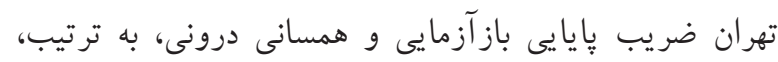

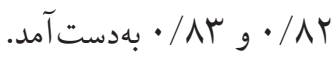

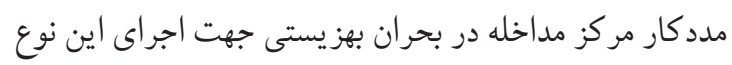

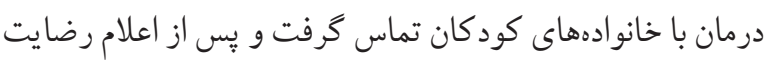

1. Beck Depression Inventory (BDI)
كروهى بر ميزان افسردكى و احساس تنهايى كودكان Y-11 اساله داراى اختلال يٍ از ضربه ناشى از سوء استفاده جنسى شهر تهران

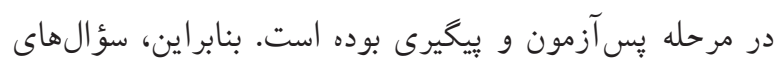

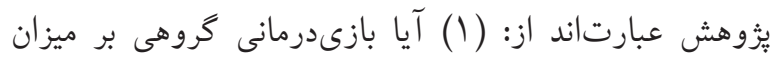

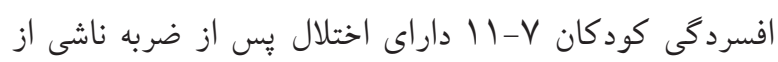

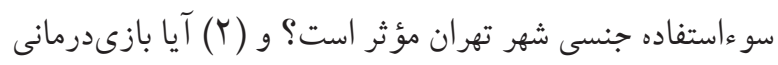

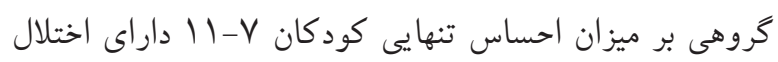

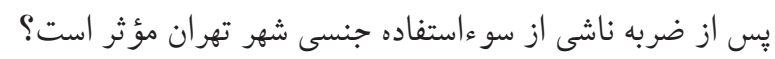

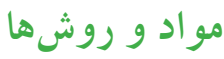

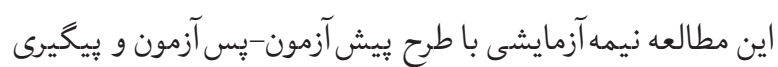

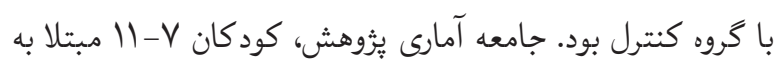

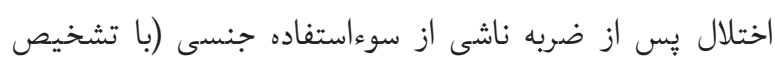
روان يزشك و بر اساس ملاك تشخيصى DSM-IV مراجعه كننده به مراكز مداخله در بحران بهزيستى استان تهران در سال سآوسا بودند. در اين بُروهش، نمونه كيرى به شيوه در دسترس انجام شدر.

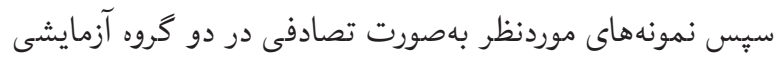

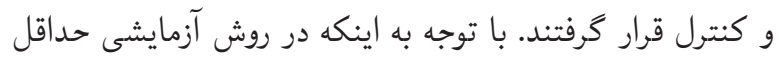

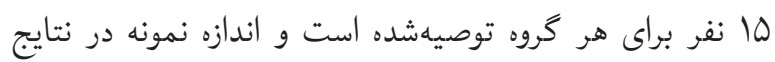

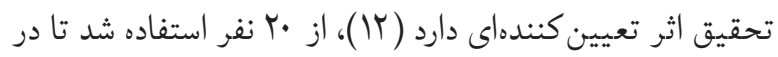

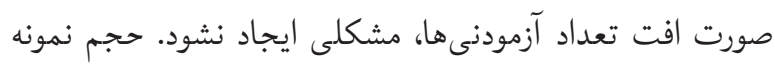

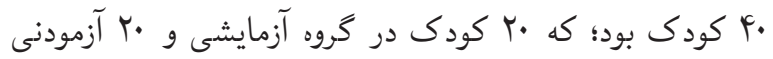

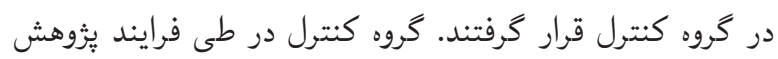

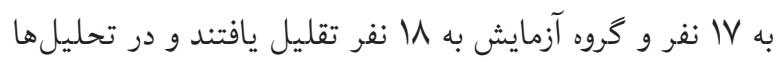

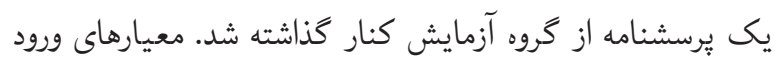

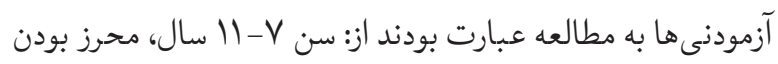

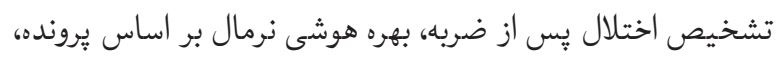

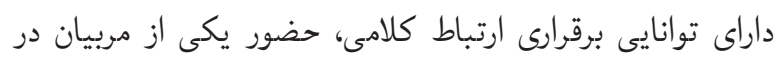
كنار كودى در طى جلسه اول، همكارى كودى با انجام مطالعه و قرار نداشتن در هيج فرايند درمانى ديكر.

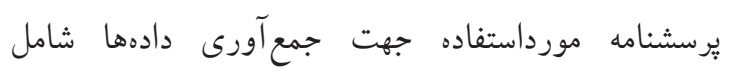


براى تهيه محتواى آموزشى از تحقيقات مؤثر قبلى (19 - 19)

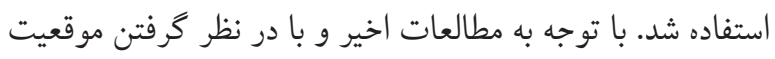
نمونه هاى تحقيق، كه امكان جلسات زياد را نداشتند، و درعين حال جلساتِ كمتر نيز نمى توانست نشاندهنده روش درمان باشد، تعداد

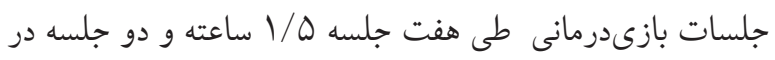
هفته در نظر گرفتهشد و به شيوه جدول زير اجراش شد.
خانوادهها دوبار با آنها تماس گرفته شد و روند كار براى آنها

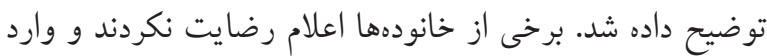
نمونه نشدند. با جهار نفر از مادران اين گروه جلسات حضورى نئ نيز

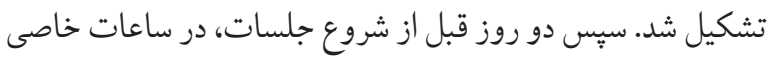

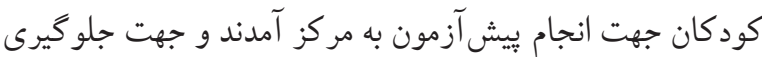

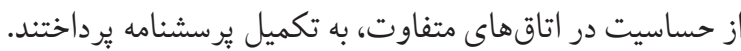

\begin{tabular}{|c|c|}
\hline 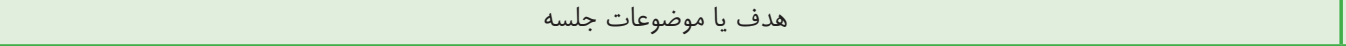 & نوبت جلسه \\
\hline لبا هدف آشنايى و ايجاد فضاى مناسب جهت آموزش و با استفاده از بازىهاى يِيشنهادى كودكان يِيش رفت. & اول \\
\hline با موضوع شناسايى انواع احساسات كود كان و با هدف ايجاد شرايط لازم جهت برونريزى احساسات آنها صورت كرفت. & دوم \\
\hline | به بازىهاى گروهى جهت به وجود آمدن همكارى و ارتباطات اجتماعى در كود كان برداخته شد. & سوم \\
\hline 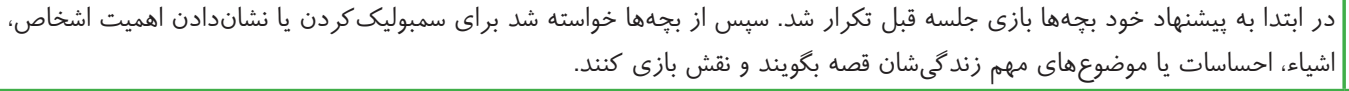 & جهارم \\
\hline بازىهاى گروهى و ايفاى نقش با هدف كشف تنهايى و اضطرابها در روابط اجتماعى صورت گرفت. & ينجم \\
\hline به انجام بازى هاى خيالى با الكوهاى خاص با هدف كمى به ابراز آرزوها، ايدهها و تمايلات و دستيابى به راهحل برداخته شد. & ششم \\
\hline 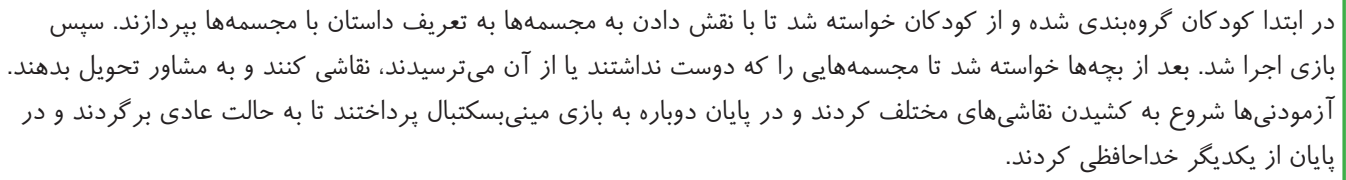 & \\
\hline
\end{tabular}

مورداستفاده قرار كرفت.

يافتهاهـا

ميانگين سنى براى گروه كنترل N/V9 سال و دامنه آن V تا II سال متغير و ميانخين گروه آزمايشى 9 بود. ملاحظه مى كردد

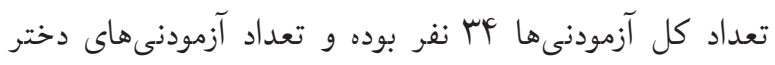

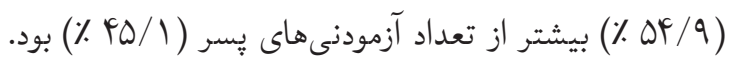

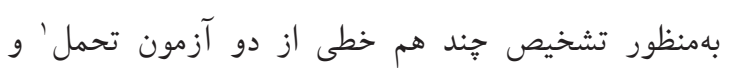

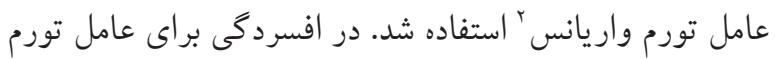

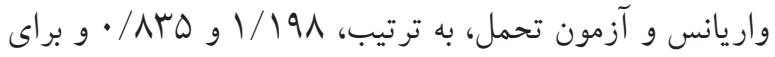

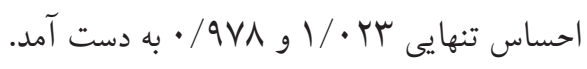

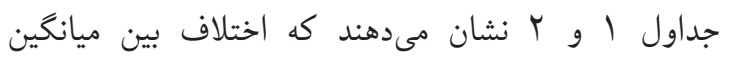
افسردگى و احساس تنهايى قبل و بعد از مداخله معنادار بود و

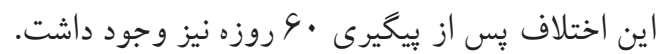

1. Tolerance

2. variance inflation factor (VIF)

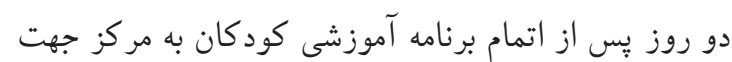
انجام آزمونهاى يس آزمون آمدند و به هر كدام هديهاى داده شد.

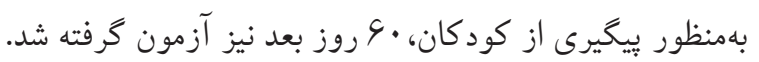

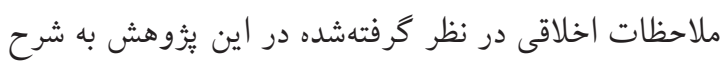

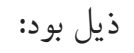
1- هيج كودكى بدون اجازه والدين و رضايت خود كودى وارد مداخله نشد. Y-هيج گونه نام و نام خانواد گى از كود كان ثبت نشد و صرفاً سن و جنسيت آنها درج گرديد. r-هيج گونه تصو يربردارى صورت نكرفت F دادههاى جمع آورىشده توسط T. SPSS تحليل شدند. جهت بررسى يافتهاى توصيفى از ميانخين و انحراف استاندارد

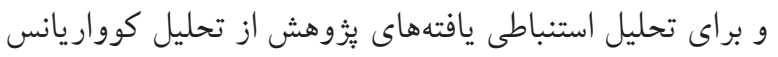
جهت تعيين اثربخشى روش درمانى بر متغيرهاى وابسته استفاده

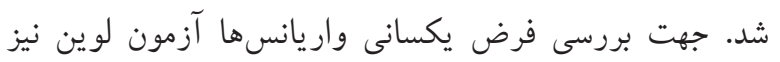


جدول r. يافتهاى توصيفى احساس تنهايى گروههاى آزمايش و كنترل در ييش آزمون، يسآ

\begin{tabular}{|c|c|c|c|c|}
\hline انحراف استاندارد & ميانغين & تعداد & & \\
\hline r/qVAץr & $q \Lambda / \cdot r q r$ & IV & يِشآزمون & \multirow{3}{*}{ كنترل } \\
\hline F/sYQSV & $S \Lambda / \cdot \Delta \Lambda \Lambda$ & IV & يس آزمون & \\
\hline$r / \cdot \Delta V \cdot \varphi$ & SN/YqFI & IV & يیيخيرى & \\
\hline$F / . q F F V$ & $V \cdot / \Delta r q F$ & IV & يِيش آزمون & \multirow{3}{*}{ بازى درمانى } \\
\hline F/FVOFT & SI/ArrA & IV & ״س آزمون & \\
\hline$\Delta / r \Delta \cdot r \mu$ & $s \Delta / \ldots$ & IV & 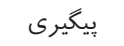 & \\
\hline
\end{tabular}

ناشى از بازىدرمانى گروهى است. در مرحله بيخيرى نيز با حذف اثر ييش آزمون همجنان اثر درمان حفظشده است (F=V/99F؛

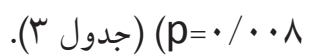

جدول ا. يافتههاى توصيفى افسردگى گروههاى آزمايش و كنترل

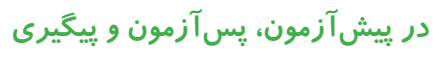

\begin{tabular}{|c|c|c|c|c|}
\hline انحراف استاندارد & ميانكين & تعداد & & \\
\hline r/sorls & $\mu G / v \cdot \Delta q$ & IV & يِيش آزمون & \multirow{3}{*}{ كنترل } \\
\hline$r / 8 \mu \cdot 90$ & rs/afir & IV & يس آزمون & \\
\hline F/|S|rV & rs/VGFV & IV & يیيخيرى & \\
\hline$p / 1 . p r q$ & $r V / V \cdot \Delta q$ & IV & ييش آزمون & \multirow{3}{*}{ بازىدرمانى } \\
\hline 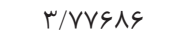 & rF/OrqF & IV & ״ֶ آزمون & \\
\hline r/s991V & $r F / q F I r$ & IV & ييخيرى & \\
\hline
\end{tabular}

نتايج نشان دادند بين ميانكين افسردگى در گروه آزمايش و

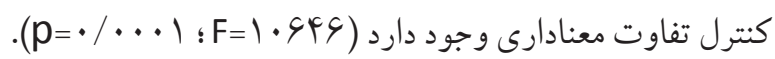

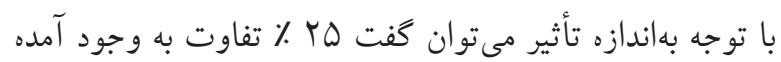

جدول س. نتايج تحليل كوواريانس روى نمرههاى يسآزمون افسردگى در گروه بازىدرمانى و گواه با كنترل ييشآزمون

\begin{tabular}{|c|c|c|c|c|c|c|c|}
\hline ميزان تأثير & سطح معنادارى & F & ميانگين مجذورات & df & مجموع مجذورات & منبع & متغير وابسته \\
\hline$\cdot / F \vee A$ &.$/ \cdots 1$ & rN/rUS & $r \cdot q / \Lambda \cdot s$ & 1 & $r \cdot q / \Lambda \cdot s$ & يِش آزمون & \multirow{4}{*}{ "افسرد آزمون } \\
\hline \multirow[t]{3}{*}{$\cdot / T \Delta S$} &.$/ \cdot r$ & $1 . / 445$ & VA/VGV & 1 & VA/VSV & كروه & \\
\hline & & & $V / \mu q 9$ & r & $r q / r V \mid$ & خطbا & \\
\hline & & & & $\mu F$ & $q r q \cdot v / \ldots$ & مجموع & \\
\hline$\cdot / D S F$ &.$/ \cdots$ & $r \cdot / \cdot s q$ & $r \vee q / s r$. & 1 & $r \vee q / s r$. & يِش آزمون & \multirow{4}{*}{ افِيردگى } \\
\hline \multirow[t]{3}{*}{$\cdot / r \cdot \Delta$} & $\cdot / \cdots \wedge$ & V/99r & $\Delta \Delta / V \wedge q$ & 1 & $\Delta \Delta / V \wedge q$ & كروه & \\
\hline & & & $9 / 91$. & r & $r \mid s / r v$. & خطا & \\
\hline & & & & mp & frerg/... & مجموع & \\
\hline
\end{tabular}

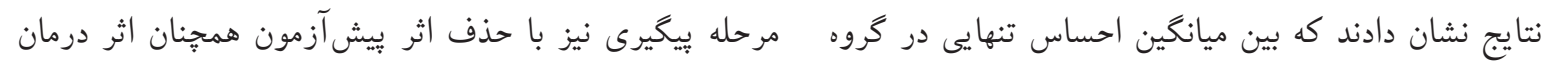

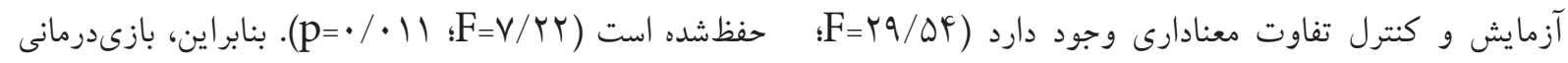

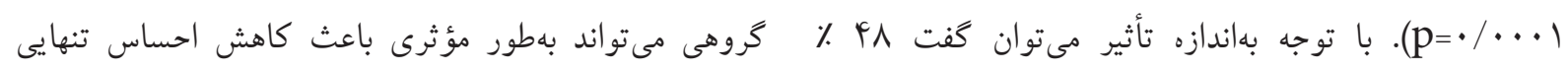

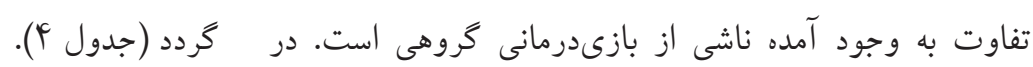

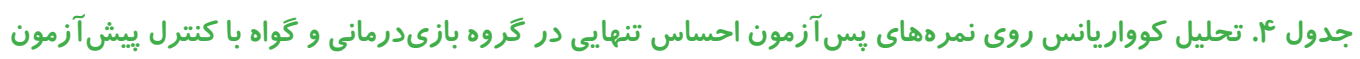

\begin{tabular}{|c|c|c|c|c|c|c|c|}
\hline ميزان تأثير & سطح معنادارى & F & ميانغين مجذورات & df & مجموع مجذورات & منبع & متغير وابسته \\
\hline$\cdot / r V F$ &.$/ \cdot r$ & $11 / V 1 \wedge$ & $|1| / 919$ & 1 & $|1| / 919$ & يِش آزمون & \multirow{4}{*}{ احساس تنهايى } \\
\hline \multirow[t]{3}{*}{$\cdot / F \wedge \Lambda$} &.$/ \ldots$ & $r q / \Delta F F$ & FON/AIV & 1 & FON/AIV & كروه & \\
\hline & & & $10 / \Delta \mu$. & r & FNI/FYG & خطا & \\
\hline & & & & mp & $\mid F F r \wedge F / \ldots$ & مجموع & \\
\hline$\cdot / \cdot \wedge \mathrm{V}$ & .1 .90 & $r / 9 \& V$ & $\Delta \mu / . \& \Lambda$ & 1 & $\Delta r / . G \wedge$ & يِش آزمون & \multirow{4}{*}{ احراس تنهايىى } \\
\hline \multirow[t]{3}{*}{.$/ 119$} & $.1 \cdot 11$ & $V / Y Y I$ & Irq/IFs & 1 & Irq/IFs & كروه & \\
\hline & & & IV/AMS & $\mu_{1}$ & $\Delta F Y / F G Y$ & خطا & \\
\hline & & & & $m p$ & IOIVTr/... & مجموع & \\
\hline
\end{tabular}


سرطانى اشاره كردهاند. او گاوا (^) نيز بيان كرد كه بازىدرمانى يك مداخله درمانى مؤثر براى كودكان آسيبديده و كودكانى

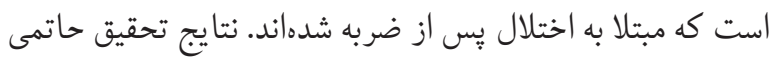

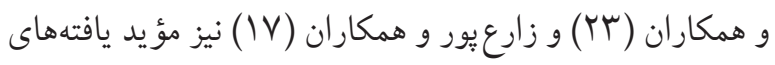
اين يثزوهش هستند.

يافتها حاكى از كاهش ميزان احساس تنهايى پِ إز از مداخله

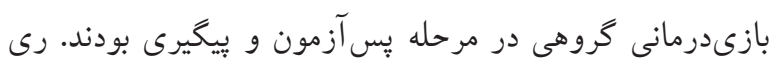
(YF)

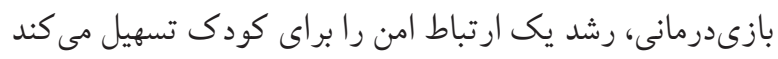

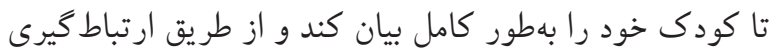

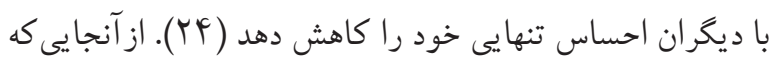

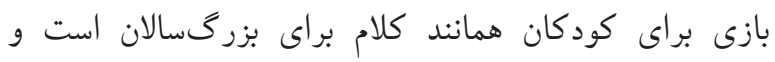

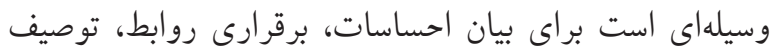

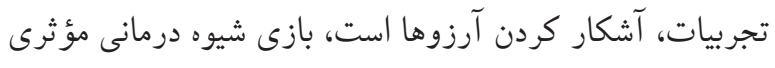

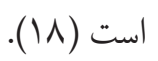

نتايج بررسى زارع يور و همكاران (IV) كه به بررسى تأثير بازىدرمانى گروهى در كودكان مبتلا به سرطان يرداخت، نتايج

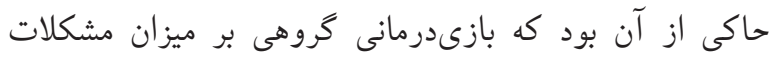

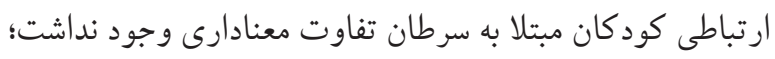

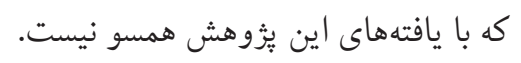

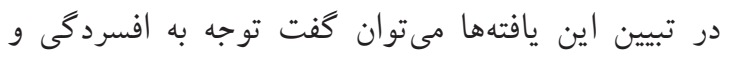

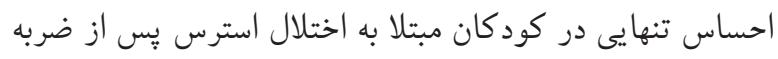

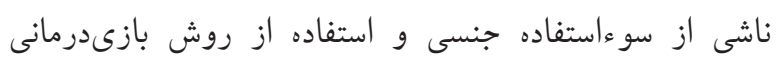
كروهى جهت ايجاد فرصت برقرارى ارتباط و وبيشخيرى از از

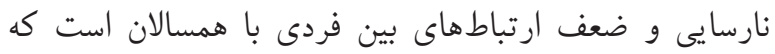
به نارضايتى از روابط اجتماعى با ديخر كودكان منجر مىشود

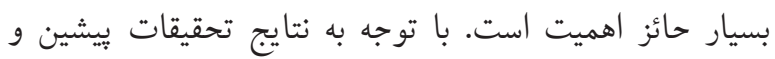

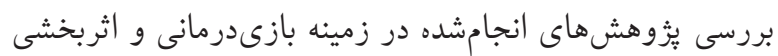

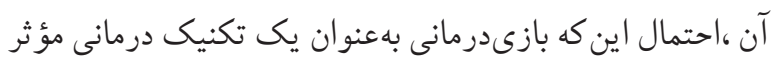

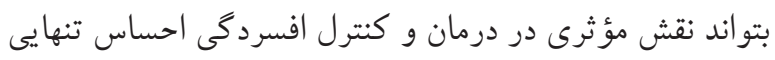

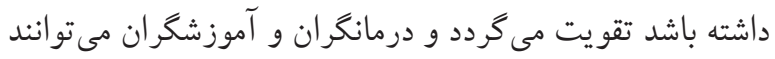

كود كان قربانى سوءاستفاده جنسى دجار مشكلاتى ازجمله اختلال استرس پس از ضربه، افسردگى، احساس تنهايى و بسيارى از مشكلات ديخر مىشوند. براى كمك به اين كود كان بايد از

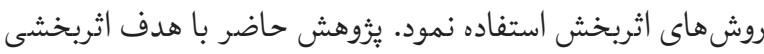

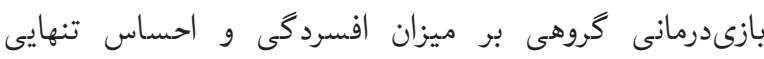

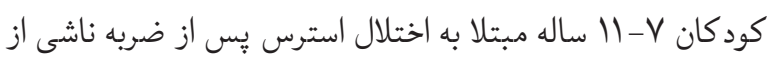
سوءاستفاده جنسى در شهر تهران انجام شد. يافتهها نشان داد كه ميان گروه آزمايش و كنترل، در ميزان تشدران

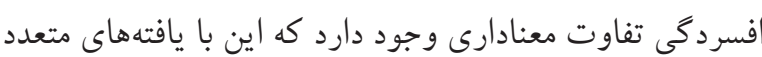

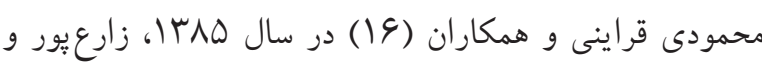

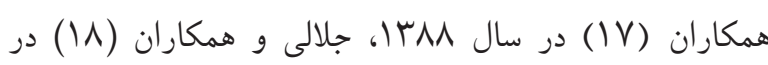

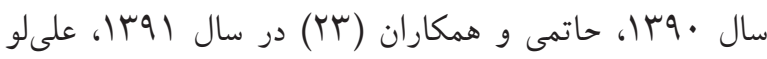

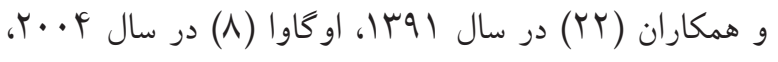

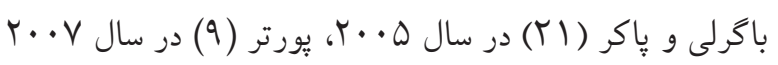

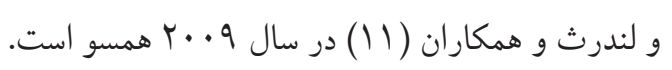
در اين راستا محمودى قراينى و همكاران (1) (1) در سال

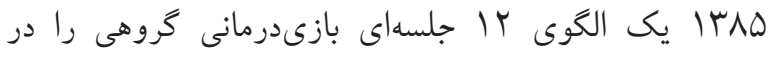
كودكان ץ تا 9 سال بازمانده از زلزله بم بكار بردند. بر اساس باس

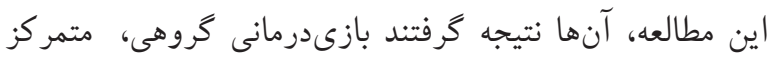

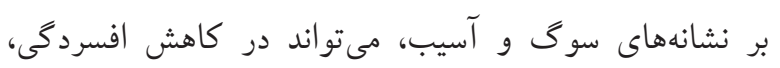

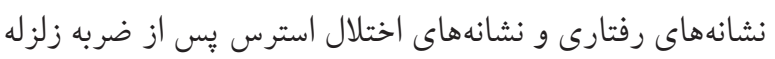

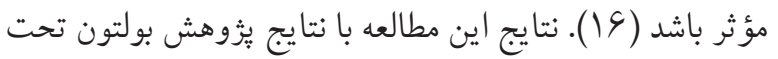

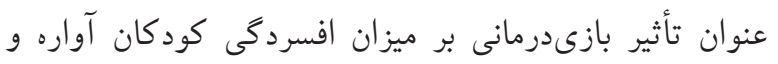

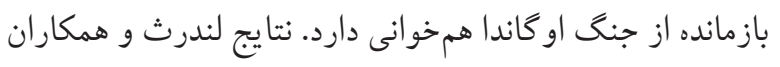

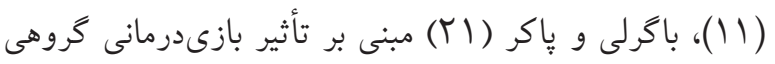

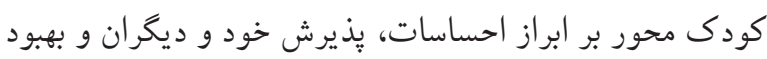

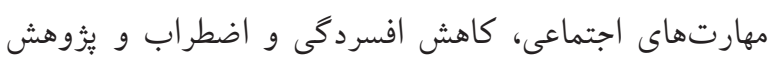

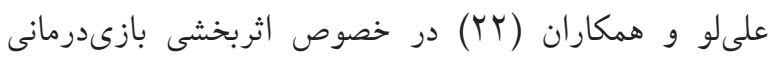

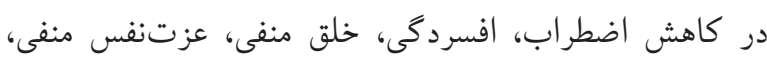

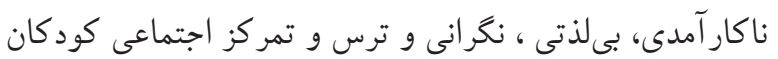




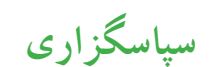

بدينوسيله از تمامى افرادى كه در اين مطالعه با يثوهشخران

همكارى نمودند، بهويثه كودكانى كه در جلسات بازى بدرمانى

كروهى شركت نموده، خانواده ايشان و مسئولين مراكز مداخله در

$$
\text { بحران بهزيستى تشكر و قدردانى مى كردد. }
$$

منابع مالى: اين طرح با هزينه هاى شخصى يثوهشگران صورت

$$
\text { يذيرفته و هيج گونه حامى مالى نداشته است. }
$$

\section{References:}

1. Mikton $C$, Butchart A. Child maltreatment prevention:A system review of reviews. Bull WHO (2009);87:353-61.

2. Mirzaii J, khodaii M, Mohammadkhani P. The impact of sexual violence in detection of post-traumatic stress disorder(PTSD), Journal of Rehabilitation. 2006; vol 7, no 4. [Persian]

3. Lopez Castroman Jorge, Melhem Nadine, Birmahe Boris, Greenhil Laurence, Kolko David, Stanl Barbara, and et al. Early childhood sexual abuse increases suicidal intent,Journal of World Psychiatry. 2013;12 (2):149-154.

4. Finkelhor D, Turner H, Ormrod R and Hamby S.L. (2009). Violence,abuse, and crime exposure in a national sample of children and youth.Pediatrics, 124,1411-1423. doi:10.1111/j.147-6402.2009.01503.x

5. According to the first quarter of 1383.www.irsprc.org. [Persian]

6. Cohen Judith A, Deblinger Esther, Mannarin O, Anthony P and Steer Robert. A multi-site,randomized controlled trial for children with abuse-related PTSD symptoms, J AM Acad Child Adolesc Psychiatry. 2004;43 (4):393-402.

7. Wethingtone HR, Hahn RA, Fuqua-Whitley DS, FuquaWhitley TA, Liberman AM, Moscicki E. The effectiveness of interventions to reduce psychological harm from traumatic events among children and adolescents:a systematic review.American journal of preventive medicine. 2008;35 (3):287-313.

8. Ogawa Y. (2004). Childhood trauma and play therapy intervention for traumatized children. Journal of professional consseling: practice theory and research, 32(1): 19-29.

9. Porter ML \& Hernandes-Rie M. Play therapy. Philadelphia: Taylor and Francis. 2007; p:1-16.

10. Jones KD. Group play therapy with sexuality abused preschool children:group behaviors and interventions. Journal for specialists in group work. 2002;27 (4):377-389.

11. Landreth, G.L., D.C. Ray, and S.C. Bratton, Play therapy in elementary schools. Psychology in the Schools, 2009.

$$
\begin{aligned}
& \text { از آن در مراكز خود استفاده نمايند. } \\
& \text { نتيتجه كيرى: با توجه به اينكه سوءاستفاده جنسى در كودكان } \\
& \text { باعث بروز مشكلاتى مىشود كه مىتواند در تمام طول عمر فرد } \\
& \text { اثرگذار باشد، استفاده از رويكردهاى درمانى مبتنى بر بازىهاى } \\
& \text { كروهى مى تواند از مشكلاتى نظير افسردكى و احساس تنهايى } \\
& \text { اين كودكان بهطور مؤثرى بكاهد. }
\end{aligned}
$$$$
\text { 46(3): p. 281-289. }
$$

12. Delavar A, Theoretical and practical research in the humanities and social sciences, Roshd,2002. [Persian]

13. Azadfarsani Y, Parsaii S, Darabi E and Alvandi Z. Psychometric scale of lonely child at school. Journal of Knowledge and Research in Applied Psychology.2012;14(1):42-43. [Persian]

14. Rajabi GH, Attari Y. Children's Depression Inventory analysis. Journal of News and Councelling Research. 2002;1(9-10):83-102. [Persian]

15. Dehshiri GH, Nagafi M,sheikhi M, Habibi M. A primairy study on the psychometric properties of Children's Depression Inventory. Journal of Family Studies. 2009;5(18):159-173. [Persian]

16. Mahmudi gharaii J, Bina M, Yasami M, Emami A, Naderi F. Effect of group play therapy on symptoms associated with grief and damage caused by the incident Bam earthquake in children 3 to 6 years: A before and after study. Journal of Iranian Pediatrics.2006;16(2). [Persian]

17. Zarepour A, Fallahi Khoshknab M, Kashani Nia Z, Biglarian A, Babashahabi R. Effect of group play therapy on depression in children with cancer. Journal of Kurdistan University of Medical Sciences. (2009);14:64-72. [Persian]

18. Jalali S, Kar Ahmadi M, Molavi H, Aghaii A. Effect of group play therapy based cognitive - behavioral on social fear in children. Journal of Research in Behavioral Sciences. 2011;9(2):32-43. [Persian]

19. Bakhshipour E, Rahnama N, Surtigi H, Eskandari Z, Izadi Najafabadi S. The effect of aerobic exercise program and group play therapy on balance of children with ADHD. Journal of Research in Rehabilitation Sciences. 2013;9(2). [Persian]

20. Blanco, P.J. and D.C. Ray, Play therapy in elementary schools: A best practice for improving academic achievement. Journal of Counseling and Development: JCD, 2011. 89(2): p. 235.

21. Baggerly, J., \& Parker, M., (2005). Child-centered group play therapy with African American boys the elementary 
school level, Journal of Counseling \& Development, 83. 387-396.

22. Alilu M, Hashemi T, Farshbaf Manisefat F. (2012). The effectiveness of play therapy according levy approach in reduction of anxiety in children with diagnosed cancer, Tabriz universiy, psychology Department. [Persian]

23. Hatami Z, Yousefi M, Delavar A. (2012). Effect of group play therapy in reducing depressive symptoms in depressed children. Journal of School Counselor Growth, 28:20-56. [Persian]

24. Ray, D. (2004). Supervision of basic of advanced skills in play therapy. Journal of

Profesional Counseling: Practice, Theory \& Research. 32(2):2841. 